\title{
Executive Power, Social Capital, and Stock Crashes
}

Zhi-Qiang LIU ${ }^{a^{*}}$, Tong ZHOU ${ }^{b}$

\author{
School of Finance, Yunnan University of Finance and Economics, Kunming, China \\ a369276515@qq.com, b476863684@qq.com
}

${ }^{*}$ Corresponding author

Keywords: executive power, social capital, stock crash

\begin{abstract}
This paper uses the data of Shanghai and Shenzhen A-share listed companies from 2005 to 2015, according to the empirical test examines the impact of management power and the level of social capital in the company's region on the company's stock collapse risk. It turns out that the greater the power of management is, the greater the risk of the company's share price collapse will be; the higher the level of social capital in the company's location, the lower the risk of the company's share price collapse can be. And in areas with high level of social capital, the impact of management power on the risk of stock price crash has dropped significantly. The conclusions of this paper illustrate the effective supervision of management power, efforts to strengthen the construction of social capital level are of great significance for preventing and avoiding the risk of stock market crash.
\end{abstract}

\section{Introduction}

China's academic research on stock crashes is relatively late compared to foreign countries', existing literature mainly from securities analysts(Yue Pan et al., 2011; Xu Nianxing et al., 2012), gender characteristics of CEO and $\mathrm{CFO}(\mathrm{Li}$ Xiaorong, Hang Liu, 2012b), tax collection and management(Jiang Xuanyu, 2013b), herd behavior of institutional investors(Xu Nianxing et al., 2013b), media reports and institutional environment(Luo Jinhui and Du Xingqiang, 2014b), legal protection of investors(Wang Huacheng et al., 2014), the factors affecting the risk of stock collapse have been studied. However, existing researches ignored the impact of corporate executive power and social capital levels in the company's region on stock crashes. Therefore, the purpose of this paper is to examine the impact of executive power and social capital on stock crashes.

This article takes the 2005-2015 Shanghai and Shenzhen A-share listed companies as a research sample, tested the impact of executive power and social capital on stock crashes. The study found, when other conditions remain unchanged, company executive power is positively related to stock market risk, the level of social capital in the company's region is negatively correlated with the stock crash risk, and further research findings that in areas with high levels of social capital, the adverse effects of executive power on the risk of stock crashes have been significantly weakened.

The research contribution of this paper is mainly reflected in the following aspects: First of all, this paper further enriches the related researches on the personal characteristics of executives and the risk of stock collapse. In addition, this paper further expands the impact of external governance mechanisms on stock market crash risk.

The rest of the structure of this paper is organized as follows: The second part is the theoretical analysis and proposing the hypothesis; the third part is the research design and empirical test results; the fourth part is the robustness test; the fifth part is the conclusion of the study.

\section{Theoretical Analysis and Hypothesis}

According to the stock price collapse theory, which based on incomplete information rational expectation equilibrium framework, the stock price crash is the result of the centralized release of private information from informed traders and the promotion of uninformed traders(Cao et al., 2002). Company management motivates by option exercise, position promotion, enterprise empire 
building, tending to hide bad news like operating losses, this kind of behavior that hides the negative news of the company will cause the company's stock price to be seriously overestimated and generate bubbles, yet, as the time goes by, when the accumulated bad news reaches the limit, and even can't continue to hide, the bubbles will burst, all of the bad news will suddenly be released to the market, in turn, it has a great negative impact on the company's stock price and eventually collapsed, especially for companies with low information transparency, because investors can't perceive negative information which managers hided, managers are more likely to manage information, therefore, in the future, its share price will have a greater risk of collapse(Kothari et al., 2009; Ball, 2009; Kim et al., 2011a). Thus, the main reason for the risk of stock price collapse is the information opaque caused by proxy problems, then resulting in accumulation and instantaneous release of bad news(Jin \& Myers, 2006; Hutton et al., 2009). Nevertheless, under the framework of agency theory, company executives with power occupy key positions in the company's board of directors, by controlling the nomination, differentiation and drawing board members over to their side, moreover, gradually controlling the company's board of directors, and then grasping the company's actual control, and using the power in hand to formulate a compensation contract that is beneficial to them, or through earnings management to achieve performance targets(Bebchuk \& Fried, 2003; Fang Junxiong, 2011; Quan Xiaofeng et al., 2010). Company executives will also use their power to get more on-the-job consumption to maximize personal income, furthermore, they will also use their power to intervene in the selection of independent directors, choosing a person with good ties as an independent director(Liu Cheng et al., 2012). By controlling key resources of the enterprise, executives with greater power can also continuously accumulate proprietary human capital and other means to improve their replacement costs to reduce the efficiency of board governance(Arrow, 1962), the efficiency of the board will decline as the executives' powers continue to increase(Hermalin \& Weisbach, 1998). Meanwhile, the greater the executive power is, they are more likely to blindly pursue the construction of a huge corporate empire and more incline to overinvest, which means, choosing a investment project with high-risk but negative net present value(Dong Hongye, Li Xiaorong, 2014), increasing volatility in the company's operating performance(Quan Xiaofeng et al., 2010).

In consequence, this article believes that the greater the executive power is, the greater the influence of executives on the company will be, thus, leading to a decline in the efficiency of internal corporate governance, executives have more space and possibilities for information manipulation, they are more capable to hide the company's losses and other unfavorable information, and adopting various means to delay the disclosure of bad news to decline corporate's information transparency, in turn, improving the possibilities of company stock crash risk. As a result, based on the analysis above, this paper proposes the following hypothesis:

Hypothesis 1: The greater management power is, the higher the risk of the company's future share price collapse will be.

Although China is a low-trust country, geographic and cultural differences between regions in China, resulting in significant differences in the level of social capital in various regions(Zhang Weiying, Ke Rongzhu, 2002), therefore, the executives of listed companies in China will inevitably be affected and constrained by the level of social capital in their region, in areas with high levels of social capital, there are lots of social groups and organizations(Putnam et al., 1994), members of society exchange more widely with each other, information interchange and communication are more smooth and convenient, the level of trust and moral constraints are also higher, company executives are less likely to have moral hazard, namely by using the power in the hands to maximize personal interests, opportunism and speculation that hide bad news are also less. Besides, in areas with high levels of social capital, the level of mutual trust between members of society is also high, even executives have a lot of power, under the moral constraints of society, in the consideration of their own reputation, executives will avoid abuse of power and damage reputation, even losing the trust of members of society. In contrast, in areas with low levels of social capital, executives who lack the constraints of social ethics are more likely to have opportunistic behavior and moral hazard, tend to projects with higher investment risks, pay attention to excessive pursuit of 
potential gains from company decisions but ignore potential risks, and use the power in the hands to hide bad news(Lewellyn \& Muller-Kahle, 2012).

Therefore, based on the analysis above, this paper proposes the following hypothesis:

Hypothesis 2: When the company is located in an area with a higher level of social capital, the risk of a stock price crash in the future can be lower.

Hypothesis 3: When the company is located in an area with a higher level of social capital, the influence of management power on the risk of stock price collapse will be weakened.

\section{Research Design}

\subsection{Sample selection and data source}

This article takes the 2005-2015 Shanghai and Shenzhen A-share listed companies as a research sample, and processed the data according to the following principles: (1)Excluding financial and insurance listed companies; (2) Excluding ST and PT companies; (3) Exclude companies with less than 30 weekly yield observations, in order to ensure the reliability of the calculation of the stock price crash index; (4) Excluding samples with missing financial data; (5)For the sake of avoiding the effects of singular values, this paper also performs Winsorize processing on $1 \%$ of continuous variables. Finally, 17259 observation samples were obtained.

The social capital data of this paper is derived from(Zhang Weiying, Ke Rongzhu, 2002), Financial data from CSMAR and WIND databases.

\subsection{Variable definitions and metrics}

\subsubsection{Stock price collapse risk}

$$
r_{i, t}=\beta_{0}+\beta_{1} r_{M, t-2}+\beta_{2} r_{M, t-1}+\beta_{3} r_{M, t}+\beta_{4} r_{M, t+1}+\beta_{5} r_{M, t+2}+\varepsilon_{i, t}
$$

This paper draws on methods such as Hutton et al. (2009) and Kim et al. (2011), in the first place, using the model (1) to eliminate the impact of market factors on individual stock returns,

$$
r_{i, t}=\beta_{0}+\beta_{1} r_{M, t-2}+\beta_{2} r_{M, t-1}+\beta_{3} r_{M, t}+\beta_{4} r_{M, t+1}+\beta_{5} r_{M, t+2}+\varepsilon_{i, t}
$$

In model (1), $r_{i, t}$ is Company i's t-week stock return, $r_{M, t}$ is market weighted average yield for week $\mathrm{t}$, Residual $\varepsilon_{i, t}$ is part of the weekly earnings that cannot be explained by fluctuations in market weekly yields, this article will define $\mathrm{W}_{\mathrm{i}, \mathrm{t}}=\ln \left(1+\varepsilon_{i, t}\right)$ as the specific weekly rate of return for company $i$.

Next, This article uses two indicators to measure the risk of stock price crash.

The first indicator is the negative degree of stock week earnings(Expressed by $N s k e w_{i, t}$ ), the value is equal to the inverse of the third-order moment of each company's annual weekly return and the standard deviation of the weekly return is the opposite of the quotient of the third party, specific algorithm as formula (2).

$$
\text { Nskew }_{i, t}=-\left[n(n-1)^{3 / 2} \sum W_{i, t}^{3}\right] /\left[(n-1)(n-2)\left(\sum W_{i, t}^{2}\right)^{3 / 2}\right]
$$

In this formula, $\mathrm{n}$ is the number of weeks that the company $\mathrm{i}$ traded in the t-year, the bigger Nskew $_{i, t}$ is, it means that the degree to which the company's stock return rate is negatively negative, the company's share price collapse risk will be higher.

The second indicator is the weekly income fluctuation ratio(Expressed by Duvol $_{i, t}$ ), the specific calculation method is, firstly, dividing all weekly earnings of each company into two groups, according to whether they are higher or lower than the average, then calculating the standard deviation of the two groups separately, Duvol $l_{i, t}$ is the natural logarithm of the standard deviation below the mean and the standard deviation from the mean, specific algorithm as formula (3). 


$$
\operatorname{Duvol}_{i, t}=\log \left\{\left[\left(n_{u}-1\right) \sum_{D o w n} W_{i, t}^{2}\right]\right\} /\left[\left(n_{d}-1\right) \sum_{U p} W_{i, t}^{2}\right]
$$

In this formula, $\mathrm{n}$ is the number of weeks that the company $\mathrm{i}$ traded in the $\mathrm{t}$-year, $\mathrm{n}_{\mathrm{u}}$ and $n_{d}$ are respectively the weekly return rate for the company i is higher or lower than the weekly average of the current year's return rate, when the Duvol $_{i, t}$ is bigger, it means that the degree of return to the left is greater, the company's share price collapse risk will be higher.

\subsubsection{Management power (Power $i, t)$}

This article draws on existing literature practices(Finkelstein, 1992; Fan et al., 2013; Grinstein\& Hribar, 2004; Quan Xiaofeng et al., 2010; Zhao Xi, Zhang Xishuan, 2013), making use of two methods to measure management power: the first one is the condition of the general manager is also the chairman of the company (Both $i, t$ ), if the general manager is also the chairman, it shows that the power to represent management will be greater, take the value 1 , otherwise the value 0 ; the second one is the natural logarithm of the number of shares held by executives (Excuhldnn $i, t$ ), the larger the value is, the greater the power of management can be.

\subsubsection{Social capital level(Social $i, t)$}

Drawing on existing domestic literature practices(Zhang Weiying, Ke Rongzhu, 2002; Pan Yue et al., 2009; Pan Yue et al., 2010), this article adopts(Zhang Weiying, Ke Rongzhu, 2002)the trust degree data of various provinces, municipalities and autonomous regions in mainland China to measure the level of social capital in the region where the listed company is located.

\subsubsection{Control variables}

By referencing the way of Kim \& Zhang(2016) and (Xiaofeng Quan et al., 2015), this article controlled the following variables: Negative Skewness week income $\left(\operatorname{Ncskew}_{\mathrm{i}, \mathrm{t}}\right)$, Investor heterogeneity(Dturn $i, t+1)$, Market fluctuation(Sigma $i, t+1)$, Market income(RET $i, t+1)$, Financial leverage(Lev $\mathrm{i}, t+1)$, Company asset size $\left(\operatorname{Size}_{i, t+1}\right)$, Market value book ratio(M/B $\left.i, t+1\right)$, Rate of Return on Common Stockholders' Equity $\left(\mathrm{ROE}_{\mathrm{i}, \mathrm{t}+1}\right)$, Information opacity(Opaque $\left.\mathrm{i}, \mathrm{t+1}\right)$.

\subsection{Model design}

In order to test the hypothesis proposed in this paper, this article referred to lots of literatures, such as Hutton et al.(2009) and (Quan Xiaofeng et al., 2015) and so on, established regression model (1) and regression model (2), tested the impact of management power and social capital on stock market crash risk separately, details as follows:

$$
\begin{aligned}
& \text { Nskew }_{i, t+1} \text { D }_{\text {uvol }}, t+1 \\
&=\beta_{0}+\beta_{1} \text { Power }_{i, t}+\beta_{2} \text { Nskew }_{i, t}+\beta_{3} \text { Dturn }_{i, t}+\beta_{4} \text { ROA+ } \beta_{5} \text { Lev }_{i, t} \\
&+\beta_{6} M / B_{i, t}+\beta_{7} \text { Size }_{i, t}+\beta_{8} \text { RET }_{i, t}+\beta_{9} \text { Sigma }_{i, t}+\beta_{10} \text { Opaque }_{i, t}+\sum \text { Year } \\
&+\sum \text { Industry }+\varepsilon
\end{aligned}
$$

In this formula, $\beta_{0}$ is the intercept term, $\varepsilon$ is the residual item, $\beta_{1}-\beta_{13}$ is the regression coefficients.

$$
\begin{aligned}
\text { Nskew }_{i, t+1} / \text { Duvol }_{i, t+1} & \\
& =\beta_{0}+\beta_{1} \text { Social }_{i, t}+\beta_{2} \text { Nskew }_{i, t}+\beta_{3} \text { Dturn }_{i, t}+\beta_{4} R O A+\beta_{5} \text { Lev }_{i, t} \\
& +\beta_{6} M / B_{i, t}+\beta_{7} \text { Size }_{i, t}+\beta_{8} \text { RET }_{i, t}+\beta_{9} \text { Sigma }_{i, t}+\beta_{10} \text { Opaque }_{i, t}+\sum \text { Year } \\
& +\sum \text { Industry }+\varepsilon
\end{aligned}
$$


In this formula, $\beta_{0}$ is the intercept term, $\varepsilon$ is the residual item, $\beta_{1}-\beta_{13}$ is the regression coefficients.

\section{Empirical Results and Analysis}

\subsection{Descriptive statistical analysis}

Table1 Descriptive statistical analysis of main variables.

\begin{tabular}{|c|c|c|c|c|c|c|}
\hline Variable & $\begin{array}{c}\text { Number of } \\
\text { samples }\end{array}$ & Mean & $\begin{array}{c}\text { Standard } \\
\text { deviation }\end{array}$ & $\begin{array}{c}\text { Minimum } \\
\text { value }\end{array}$ & Median & $\begin{array}{c}\text { Maximum } \\
\text { value }\end{array}$ \\
\hline Ncskew $_{\mathrm{i}, \mathrm{t}+1}$ & 4128 & -0.0100 & 0.0200 & -0.1100 & -0.0100 & 0.2000 \\
\hline Duvol $_{\mathrm{i}, \mathrm{t}+\mathrm{l}}$ & 4128 & -0.2900 & 0.4800 & -2.4900 & -0.2800 & 2.8300 \\
\hline Both $_{\mathrm{i}, \mathrm{t}}$ & 4128 & 0.2600 & 0.4400 & 0.0000 & 0.0000 & 1.0000 \\
\hline Excuhldnn $_{\mathrm{i}, \mathrm{t}}$ & 4128 & 12.9500 & 3.5400 & 4.6100 & 12.4100 & 20.7700 \\
\hline Social $_{\mathrm{i}, \mathrm{t}}$ & 4128 & 82.41 & 65.04 & 2.800 & 77.80 & 219 \\
\hline Ncskew $_{\mathrm{i}, \mathrm{t}}$ & 4128 & -0.0100 & 0.0500 & -0.860 & -0.0100 & 0.860 \\
\hline Dturn $_{\mathrm{i}, \mathrm{t}}$ & 4128 & 0.0300 & 0.0300 & 0 & 0.0200 & 0.380 \\
\hline
\end{tabular}

Table 1 listed descriptive statistics for the main variables, from the table, we can see that the mean of the metrics Nskew ${ }_{i, t+1}$ and Duvol ${ }_{i, t+1}$ of the explanatory variable(Company stock crash risk) separately are -0.0100 and -0.2900 , the standard deviation respectively are 0.0200 and 0.4800 , it shows that there is a big difference in the sample company among the sample companies. The mean of the executive power indicator Excuhldnn $n_{i, t}$ is 12.9500 , and the standard deviation of it is 3.5400 , which explains that there is a big difference in executive compensation between different listed companies in China; the mean of social capital level in the company's region $\left(\operatorname{Social}_{\mathrm{i}, \mathrm{t}}\right)$ is 82.21 , the maximum and minimum values of it are 219 and 2.8, while the standard deviation is 66.17, indicating that there are obvious regional differences in the level of social capital in various regions of China; descriptive statistics of other control variables are within the normal range. 


\subsection{Regression analysis}

\subsubsection{Test hypothesis 1 and hypothesis 2}

Table 2 Test results of Hypothesis 1 and Hypothesis 2.

\begin{tabular}{|c|c|c|c|c|c|c|c|c|}
\hline \multirow{2}{*}{$\begin{array}{c}\text { Variabl } \\
\text { e }\end{array}$} & (1) & (2) & (3) & (4) & (5) & (6) & (7) & (8) \\
\hline & $\begin{array}{c}\text { Nskew }_{i, t} \\
+1\end{array}$ & $\begin{array}{c}\text { Nskew }_{i, t} \\
+1\end{array}$ & $\begin{array}{c}\text { Nskew }_{i, t} \\
+1\end{array}$ & $\begin{array}{c}\text { Nskew }_{i, t} \\
+1\end{array}$ & $\begin{array}{c}\text { Duvol } \\
\mathrm{i}, \mathrm{t}+1\end{array}$ & $\begin{array}{c}\text { Duvol } \\
\mathrm{i}, \mathrm{t}+\mathbf{1}\end{array}$ & $\begin{array}{c}\text { Duvol } \\
\mathrm{i}, \mathrm{t}+\mathbf{1}\end{array}$ & $\begin{array}{c}\text { Duvol } \\
\mathrm{i}, \mathrm{t}+\mathbf{1}\end{array}$ \\
\hline \multirow{2}{*}{ Both $_{i, t}$} & $\begin{array}{c}0.0019 * \\
* *\end{array}$ & $\begin{array}{c}0.0021 * \\
* *\end{array}$ & & & $\begin{array}{c}0.0590 * \\
* *\end{array}$ & $\begin{array}{c}0.0621 * \\
* *\end{array}$ & & \\
\hline & $(0.0013)$ & $(0.0002)$ & & & $(0.0006)$ & $(0.0003)$ & & \\
\hline \multirow{2}{*}{$\begin{array}{c}\text { Excuhld } \\
\mathrm{nn}_{\mathrm{i}, \mathrm{t}}\end{array}$} & & & $\begin{array}{c}0.0003 * \\
* *\end{array}$ & $\begin{array}{c}0.0004 * \\
* *\end{array}$ & & & $\begin{array}{c}0.0097 * \\
* *\end{array}$ & $\begin{array}{c}0.0116^{*} \\
* *\end{array}$ \\
\hline & & & $(0.0002)$ & $(0.0000)$ & & & $(0.0000)$ & $(0.0000)$ \\
\hline \multirow{2}{*}{$\operatorname{Social}_{i, t}$} & & $-0.0001 *$ & & $\begin{array}{c}-0.0001 * \\
*\end{array}$ & & $\begin{array}{c}-0.0003 * \\
*\end{array}$ & & $\begin{array}{c}-0.0003 * \\
* *\end{array}$ \\
\hline & & $(0.0600)$ & & $(0.0191)$ & & $(0.0300)$ & & $(0.0097)$ \\
\hline \multirow{2}{*}{ Nskew $_{i, t}$} & & 0.0048 & & 0.0041 & & 0.0951 & & 0.0769 \\
\hline & & $(0.3480)$ & & $(0.4215)$ & & $(0.5285)$ & & $(0.6100)$ \\
\hline \multirow{2}{*}{ Dturn $_{\mathrm{i}, \mathrm{t}}$} & & -0.0132 & & $-0.0202 *$ & & -0.1390 & & -0.3254 \\
\hline & & $(0.2632)$ & & $(0.0886)$ & & $(0.6908)$ & & $(0.3561)$ \\
\hline $\begin{array}{c}\text { Control } \\
\text { variable }\end{array}$ & Yes & Yes & Yes & Yes & Yes & Yes & Yes & Yes \\
\hline \multirow{2}{*}{ Constant } & $\begin{array}{c}-0.0147 * \\
* *\end{array}$ & $\begin{array}{c}-0.0181 * \\
* *\end{array}$ & $\begin{array}{c}-0.0171 * \\
* *\end{array}$ & $\begin{array}{c}-0.0215 * \\
* *\end{array}$ & $\begin{array}{c}-0.4327 * \\
* *\end{array}$ & $\begin{array}{c}-0.4746^{*} \\
* *\end{array}$ & $\begin{array}{c}-0.5155^{*} \\
* *\end{array}$ & $\begin{array}{c}-0.5617 * \\
* *\end{array}$ \\
\hline & $(0.0000)$ & $(0.0011)$ & $(0.0000)$ & $(0.0001)$ & $(0.0000)$ & $(0.0040)$ & $(0.0000)$ & $(0.0008)$ \\
\hline $\begin{array}{c}\text { Observat } \\
\text { ions }\end{array}$ & 4,128 & 4,128 & 4,128 & 4,128 & 4,128 & 4,128 & 4,128 & 4,128 \\
\hline $\begin{array}{c}\text { Adjusted } \\
\text { R-square } \\
\text { d }\end{array}$ & 0.036 & 0.047 & 0.037 & 0.050 & 0.043 & 0.050 & 0.044 & 0.052 \\
\hline
\end{tabular}

Note: $* * *, * *$ and $*$ separately represent the significance levels of $1 \%, 5 \%$ and $10 \%$, The number in parentheses is the p-value of the two-tailed test.

Table 2 lists the test results for hypotheses 1 and 2. In regression (1)-(4), this paper uses Nskew $\mathrm{i}_{\text {, }}$ ${ }_{t+1}$ as a measure of stock crash risk, among regression (1) and (2), the indicator Both $_{i, t}($ whether the chairman and general manager are two-in-one) is used to measure management power, it can be discovered: In regression (1), we only controlled annual and industry effects, Both $\mathrm{i}_{\mathrm{t}} \mathrm{t}$ has a coefficient of 0.0019 , and significant at the $1 \%$ level; in regression (2), this paper controls other control variables that affect the risk of stock collapse, Both $\mathrm{i}_{\mathrm{i}, \mathrm{t}}$ has a coefficient of 0.0021 , and significant at the $1 \%$ level, $^{\text {Social }}{ }_{\mathrm{i}, \mathrm{t}}$ has a coefficient of -0.0001 , and significant at the $10 \%$; in regression (3) and (4), this article uses Excuhldnn $n_{i, t}$ (the natural logarithm of the number of shares held by executives) to measure management power, we can find that: in regression(3), this article uses Nskew $\mathrm{i}_{\mathrm{t}+\mathrm{l}}$ as a measure of stock crash risk, by controlling annual and industry effects, the coefficient of Excuhldnn $n_{i, t}$ is 0.0003 with the significant at the $1 \%$ level; in regression(4), this paper controls other control variables that affect the risk of stock collapse, the coefficient of Excuhldnn ${ }_{\mathrm{i}, \mathrm{t}}$ is 0.0004 with the significant at the $1 \%$ level, the coefficient of Social $_{i, t}$ is -0.0001 with the 
significant at the 5\% level. Considering the analyses above, we can draw a conclusion that with the improvement of management power and the increase of the level of social capital in the company's region, the risk of a stock crash in the future will also increase, hypothesis 1 and hypothesis 2 are verified.

In regression (5)-(8), this article uses Duvol $i, t+1$ as a measure of stock crash risk, especially in regression (5) and (6), the indicator Both $_{\mathrm{i}, \mathrm{t}}$ (whether the chairman and general manager are two-in-one) is used to measure management power, it can be discovered: In regression (5), we only controlled annual and industry effects, $B \mathrm{th}_{\mathrm{i}, \mathrm{t}}$ has a coefficient of 0.0590 , and significant at the $1 \%$ level; in regression (6), this paper controls other control variables that affect the risk of stock

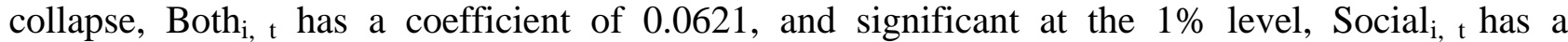
coefficient of -0.0003 , and significant at the 5\%. In regression (7) and (8), this article uses Excuhldnn $_{\mathrm{i}, \mathrm{t}}$ (the natural logarithm of the number of shares held by executives) to measure management power, we can find that: in regression(7), by controlling annual and industry effects, the coefficient of Excuhldnn $n_{i, t}$ is 0.0097 with the significant at the $1 \%$ level; in regression(8), this paper controls other control variables that affect the risk of stock collapse, the coefficient of Excuhldnn $_{i, t}$ is 0.0116 with the significant at the $1 \%$ level, the coefficient of Social ${ }_{i, t}$ is -0.0003 with the significant at the $1 \%$ level. The analyses above further validate hypotheses 1 and 2 , it shows that the research conclusion of this paper is robust.

\subsubsection{Test hypothesis 3}

Table 3 Test results of hypothesis 3 .

\begin{tabular}{|c|c|c|c|c|c|c|c|c|}
\hline & \multicolumn{2}{|c|}{$\begin{array}{c}\text { Group Lower social } \\
\text { capital }\end{array}$} & \multicolumn{2}{|c|}{$\begin{array}{c}\text { Group Higher social } \\
\text { capital }\end{array}$} & \multicolumn{2}{|c|}{$\begin{array}{l}\text { Group Lower } \\
\text { social capital }\end{array}$} & \multicolumn{2}{|c|}{$\begin{array}{l}\text { Group Higher } \\
\text { social capital }\end{array}$} \\
\hline & (1) & (2) & (3) & (4) & (5) & (6) & (7) & (8) \\
\hline Variables & $\begin{array}{c}\text { Nskew }_{i, t} \\
+1\end{array}$ & $\begin{array}{c}\text { Nskew }_{i, t+} \\
1\end{array}$ & $\begin{array}{c}\text { Nskew }_{i, t+} \\
1\end{array}$ & $\begin{array}{c}\text { Nskew }_{i, t+} \\
1\end{array}$ & $\begin{array}{c}\text { Duvol } \\
\mathrm{i}, \mathrm{t}+1\end{array}$ & $\begin{array}{c}\text { Duvol } \\
\mathrm{i}, \mathrm{t}+1\end{array}$ & $\begin{array}{c}\text { Duvol } \\
i, t+1\end{array}$ & $\begin{array}{c}\text { Duvol } \\
\mathrm{i}, \mathrm{t}+1\end{array}$ \\
\hline \multirow{2}{*}{ Both $_{i, t}$} & $\begin{array}{c}0.0025 * \\
* *\end{array}$ & & 0.0014 & & $\begin{array}{c}0.0599 \\
* * *\end{array}$ & & 0.0317 & \\
\hline & $(0.0008)$ & & $(0.1461)$ & & $\begin{array}{c}(0.0054 \\
)\end{array}$ & & $\begin{array}{c}(0.141 \\
4)\end{array}$ & \\
\hline \multirow{2}{*}{ Excuhldnn $_{\mathrm{i}, \mathrm{t}}$} & & $\begin{array}{c}0.0005^{* *} \\
*\end{array}$ & & 0.0003 & & $\begin{array}{c}0.0154 \\
* * *\end{array}$ & & 0.0061 \\
\hline & & $(0.0000)$ & & $(0.1434)$ & & $\begin{array}{c}(0.0000 \\
)\end{array}$ & & $\begin{array}{c}(0.129 \\
3)\end{array}$ \\
\hline \multirow{2}{*}{ Nskew $_{i, t}$} & 0.0033 & 0.0028 & 0.0246 & 0.0229 & 0.0284 & 0.0125 & $\begin{array}{c}0.8624 \\
*\end{array}$ & $\begin{array}{c}0.8380 \\
*\end{array}$ \\
\hline & $(0.5417)$ & $(0.6000)$ & $(0.1325)$ & $(0.1614)$ & $\begin{array}{c}(0.8570 \\
)\end{array}$ & $\begin{array}{c}(0.9367 \\
)\end{array}$ & $\begin{array}{c}(0.083 \\
9)\end{array}$ & $\begin{array}{c}(0.094 \\
0)\end{array}$ \\
\hline \multirow{2}{*}{ Dturn $_{i, t}$} & -0.0130 & -0.0189 & -0.0165 & -0.0218 & -0.0211 & -0.2263 & $\begin{array}{c}-0.263 \\
3 \\
\end{array}$ & $\begin{array}{c}-0.356 \\
9 \\
\end{array}$ \\
\hline & $(0.3885)$ & $(0.2100)$ & $(0.4108)$ & $(0.2809)$ & $\begin{array}{c}0.9617 \\
)\end{array}$ & $\begin{array}{c}(0.6078 \\
)\end{array}$ & $\begin{array}{c}(0.666 \\
6)\end{array}$ & $\begin{array}{c}(0.564 \\
7)\end{array}$ \\
\hline $\begin{array}{l}\text { Control } \\
\text { variable }\end{array}$ & Yes & Yes & Yes & Yes & Yes & Yes & Yes & Yes \\
\hline \multirow{2}{*}{ Constant } & $\begin{array}{c}-0.0170 \\
* *\end{array}$ & $\begin{array}{c}-0.0211 * \\
* *\end{array}$ & $\begin{array}{c}-0.0261 * \\
* *\end{array}$ & $\begin{array}{c}-0.0271 * \\
* *\end{array}$ & -0.3318 & $\begin{array}{l}-0.4760 \\
* *\end{array}$ & $\begin{array}{c}-0.674 \\
4 * *\end{array}$ & $\begin{array}{c}-0.664 \\
3 * *\end{array}$ \\
\hline & $(0.0218)$ & $(0.0049)$ & $(0.0049)$ & $(0.0035)$ & $\begin{array}{c}(0.1252 \\
)\end{array}$ & $\begin{array}{c}(0.0297 \\
)\end{array}$ & $\begin{array}{c}(0.017 \\
1)\end{array}$ & $\begin{array}{c}(0.019 \\
3)\end{array}$ \\
\hline Observations & 2,479 & 2,479 & 1,649 & 1,649 & 2,479 & 2,479 & 1,649 & 1,649 \\
\hline $\begin{array}{l}\text { Adjusted } \\
\text { R-squared }\end{array}$ & 0.051 & 0.055 & 0.040 & 0.041 & 0.047 & 0.053 & 0.050 & 0.049 \\
\hline
\end{tabular}


Note: $* * *, * *$ and $*$ separately represent the significance levels of $1 \%, 5 \%$ and $10 \%$, The number in parentheses is the p-value of the two-tailed test.

Table 3 lists the test results for hypotheses 3. In regression (1)-(4), this paper uses $N_{s k e w}, t+1$ as a measure of stock crash risk, among regression (1), which means samples in this group with lower social capital, Both $\mathrm{i}_{\mathrm{i}, \mathrm{t}}$ has a coefficient of 0.0025 , and significant at the $1 \%$ level; in regression (3) with group samples with higher social capital level, Both ${ }_{i, t}$ has a coefficient of 0.0025 but non-significant, it means that in areas with low levels of social capital, the influence of management power on the company's stock collapse risk is more significant, the risk of a stock crash in the future is higher, however, in areas with high levels of social capital, the impact of management power on stock market crash risk was weakened, this conclusion was preliminary verificated by hypothesis 3; in regression (2) with group samples with lower social capital level, Excuhldnn ${ }_{\mathrm{i}, \mathrm{t}}$ has a coefficient of 0.0005 and significant at the $1 \%$ level; in regression (4) with group samples with higher social capital level, Excuhldnn $n_{i, t}$ has a coefficient of 0.0003 but non-significant, hypothesis 3 is further verified.

In regression (5)-(8), this paper repeats the above test by using Duvol ${ }_{i, t+1}$ as a measure of stock crash risk, the test results are completely consistent with the conclusions above, it means that the test result of this hypothesis 3 is robust.

\section{Robustness Test}

\subsection{Endogenous test}

\subsubsection{Variable regression}

In order to ensure the robustness of the research conclusions, this article refers to the existing literature (Pan Yue et al., 2009), the empirical test of the risk of stock collapse in this paper through using the instrumental variable of unpaid blood donation rate indicates that the conclusions of the text is still robust.

\subsubsection{Effect regression}

In order to further control the company variables that may be missed and do not change over time, which may affect the regression results. This paper also retests the above model by using a fixed effect model, the results show that the research conclusions in this paper are still stable.

\subsection{Samples retest}

According to whether it is greater than or less than the median of the annual social capital level, this article divides the samples into two groups-Higher social capital group and lower social capital group, after the examination, it can be found that in the group which areas with low levels of social capital, the coefficients of the executive power proxy variables $\left(\right.$ Both $_{\mathrm{i}, \mathrm{t}}$ and Excuhld $\left._{\mathrm{i}, \mathrm{t}}\right)$ are significantly positive, it turned out that in areas with low levels of social capital, executive power has a significant negative impact on stock market risk; nonetheless, in the group which areas with high levels of social capital, the coefficient of the executive power proxy variable is positive but non-significant, which means that Executive power is constrained in areas with high levels of social capital, the influence of executive power on the company's stock crash risk has been weakened, hypothesis 3 is further verified.

\subsection{Ending the forecast window of stock crash risk}

In order to further examine the long-term impact of social capital levels on the company's future stock market crash risk, at the same time, to avoid endogenous problems caused by the stock price collapse risk and social capital level are causal, this paper extends the estimated time of stock crash risk to two and three years respectively. When extending the estimated estimation time to two years $(\mathrm{t}+2)$, the social capital and stock crash risk remain significantly negative at $1 \%$, the coefficient of interaction between social capital and executive power and the risk of stock collapse is negative but non-significant, it suggests that after the forecast window was extended for two years, hypothesis 2 
and hypothesis 3 are still true. The same is, when extending the estimated estimation time to three years $(t+3)$, the social capital and stock crash risk still remain significantly negative at $1 \%$, the coefficient of interaction between social capital and executive power and the risk of stock collapse is still negative but non-significant, it suggests that after the forecast window was extended for three years, hypothesis 2 and hypothesis 3 are still true.

\subsection{Clustering adjustment}

This paper refers to the study of Kim et al. (2011a) and Kim et al. (2011b), making use of double clustering to adjust standard error to perform t-test, from the regression results, the conclusions of this paper are still supported.

\section{Conclusion}

This article takes the 2005-2015 Shanghai and Shenzhen A-share listed companies as a research sample, and tested the impact of executive power and social capital on stock crashes. The study found that when other conditions remain unchanged, company executive power is positively related to stock market risk, meanwhile, the level of social capital in the company's region is negatively correlated with the stock crash risk, according to the further research findings that in areas with high levels of social capital, the adverse effects of executive power on stock crash risk are clearly weakened.

\section{References}

[1] Arrow, K. J., The Economic Implications of Learning by Doing, Review of Economic Studies. 29(1962) 155-173.

[2] Ball, R., Market and Political/Regulatory Perspectives On the Recent Accounting Scandals, Journal of Accounting Research. 47(2009) 277-323.

[3] Bebchuk, L. A. and Fried, J. M., Executive Compensation as an Agency Problem, Journal of Economic Perspectives. 17(2003) 71-92.

[4] Cao, H. H., Coval, J. D. and Hirshleifer, D., Sidelined Investors, Trading-Generated News, and Security Returns, Review of Financial Studies. 15(2002) 615-648.

[5] Dong Hongye, Li Xiaorong, The Executive Power of State-owned Enterprise and Overinvestment, Economic Management Journal. 10(2014) 75-87.

[6] Fang Junxiong, Managerial Power and Asymmetry of Compensation Change in China's Public Companies, Economic Research Journal. 04(2011) 107-120.

[7] Hermalin, B. E. and Weisbach, M. S., Endogenously Chosen Boards of Directors and their Monitoring of the CEO, American Economic Review. 88(1998) 96-118.

[8] Hutton, A. P., Marcus, A. J. and Tehranian, H., Opaque Financial Reports, R2, and Crash Risk, Journal of Financial Economics. 94(2009) 67-86.

[9] Jin, L. and Myers, S. C., R2 Around the World: New Theory and New Tests, Journal of Financial Economics. 79(2006) 257-292.

[10] Jiang Xuanyu. Tax Enforcement, Tax Aggressiveness and Stock Price Crash Risk, Nankai Business Review. 05(2013) 152-160. 